\title{
Should there be routine testing for human immunodeficiency virus infection in pregnancy?
}

$\mathrm{T}$

ESTING FOR HUMAN IMMUNODEFICIENCY VIRUS (HIV)

in pregnancy was discussed in a recent Canadian Paediatric Society statement (1). New information has become available since that position was taken and, therefore, it is worth revising the question posed in the title.

The following is a review of the impact of changing information on the five factors that are of critical importance in a screening program.

1. Sensitivity and specificity of the test: The testing for HIV continues to improve so that the proportion of false-positive tests has become extremely low. In addition, the tests to distinguish the infected infant from the infant with maternal antibodies only have improved so that the diagnosis in the infant can be confirmed by about six months of age instead of 15 months.

2. Acceptability and feasibility of the test: The issues discussed in the previous statement about acceptability and feasibility of testing have not changed substantially. Testing includes not only the procedure of the blood test but also counselling and the impact of the result (2). For efficiency, counselling and testing should be included in the routine care of the pregnant woman. Therefore, the issues of feasibility are the purview of those caring for pregnant women.

3. Benefit of early detection: In the previous statement the benefits of early treatment of the infected infant were discussed. However, no comment was made about prevention of transmission of HIV infection to the fetus. Recently, the results of an American study on

All material presented in Pediatric Infectious Disease Notes has been reviewed and approved by the chairperson. Canadian Paediatric Society Board and representative members of the Canadian Paediatric Society Committee on Infectious Diseases and Immunization

Correspondence: Infectious Diseases and Immunization Committee. Canadian Paediatric Society. 401 Smyth Rd. Ottawa, ON K1H 8L1. Telephone (613) 737-2728. Fax (613) 737-2794 prevention of maternal transmission by perinatal zidovudine (AZT) therapy were announced by the National Institutes of Health (3). In a randomized placebo controlled trial (ACTG Study 076), the transmission rate was $8.3 \%$ when mothers and their babies received AZT, in comparison with a transmission rate of $25.5 \%$ among those receiving placebo. The study has now been stopped because this treatment regimen has shown significant efficacy. This study still leaves many questions unanswered, such as the long term effects of AZT on the fetus and whether treatment of both the mother and baby is necessary for prevention of transmission. Nonetheless, an intervention that will reduce by twothirds the risk of transmission of the virus from the HIV-infected pregnant woman to her baby is clearly significant.

4. Disadvantages of testing: The psychosocial difficulties for an asymptomatic woman learning of her HIVpositive status must still be considered; for example, violence against women with HIV infection (4). In the previous statement the issue of the long period during which an infant has an 'indeterminate' HIV status was discussed. These issues remain but, fortunately, as the testing for HIV improves, the 'indeterminate' period becomes shorter so that currently almost all infected infants can be identified by six months of age.

5. Prevalence of disease: In recent studies of prevalence of HIV infection in women of child-bearing age in Canada, the rates were $1.13 / 10,000$ in Nova Scotia, $8.7 / 10,000$ in Newfoundland and 15.2/10,000 on the island of Montreal (5-7). These rates, though quite variable, geographically indicate that heterosexual transmission of Hrv continues to be a problem in Canada and that the number of HrV-positive pregnant women in Canada is significant.

In summary, the new evidence that the rate of transmission of HIV from mother to baby can be reduced by perinatal AZT means that screening pregnant women for HIV infection would not only affect the quality of life for 
mother and child but in many cases prevent this fatal disease in infants. This preventive strategy requires collaborative efforts by those who care for pregnant women to counsel and test for HIV and to offer AZT therapy during pregnancy; by those in the delivery room to provide peripartum AZT; and by those who care for the newborn to continue AZT therapy in the neonate and to monitor for long term effects of early drug use (8).

\section{REVISED RECOMMENDATIONS}

In the best interest of children, the Canadian Paediatric Society recommends:

1. HIV testing for all pregnant women.

2. Any HIV testing of either women or newborns should be voluntary and accompanied by appropriate confidentiality, counselling and informed consent.

3. Until further information is available, HIV-positive pregnant women and their newborns should be offered AZT therapy:

- Starting at 14 to 34 weeks' gestation, $100 \mathrm{mg}$ AZT orally five times daily for the remainder of the pregnancy.

- During labour, a loading dose of AZT $2 \mathrm{mg} / \mathrm{kg}$ intravenously over $1 \mathrm{~h}$, followed by continuous infusion of $1 \mathrm{mg} / \mathrm{kg} / \mathrm{h}$ until delivery.

- For the newborn, starting 8 to $12 \mathrm{~h}$ after birth. AZT syrup $2 \mathrm{mg} / \mathrm{kg} /$ dose qid for six weeks.

4. Pregnant women who have received AzT should be enrolled in the international Antiretroviral Pregnancy Registry, telephone 1-800-722-9292, extension 8465, fax (919) 315-8981.

5. If the mother has not been tested during pregnancy and if the mother has high risk behaviours or is from an area of high seroprevalence, then testing of the mother or newborn is recommended. If the mother refuses testing, then the infant should be followed and monitored as an infant of indeterminate HIV status.

6. HIV testing is recommended for abandoned infants or infants to be placed in foster or adoptive care, particularly if testing will facilitate decisions for placement.

7. Testing in the perinatal period must be part of a program that includes post-test counselling, retesting of the infant and medical care of the infant and mother.

\section{REFERENCES}

1. Canadian Paediatric Society Statement. Perinatal human immunodeficiency virus (HIV) testing. Can J Paediatr 1994: 1:ID94-01.

2. Health Canada. Canadian guidelines for the prevention, diagnosis, management and treatment of sexually transmitted diseases in neonates, children, adolescents and adults. Can Commun Dis Rep 1992;18(Suppl 1):174-5.

3. National Institutes of Health. Zidovudine for the prevention of HIV transmission from mother to infant. MMWR 1994:43:285-7.

4. North RL. Rothenberg KH. Partner notification and the threat of domestic violence against women with HIV infection. N Engl J Med 1993;329:1194-6.

5. Johnston BL, Haase DA, Armson BA, Lee SHS, Manley K. Hazell P. HIV seroprevalence in Halifax County Nova Scotia. Can J Infect Dis 1994;5 (Suppl D):42D. (Abst 32)

6. Ratnam S, Hankins C. The Newfoundland prenatal study of HIV seroprevalence. Can J Infect Dis 1994;5 (Suppl D):42D. (Abst 20)

7. Hankins C, Laberge C, Lapointe N, Gendron S, Tran T, O'Shaughnessy M. Geographical/socioeconomic links to HIV seroprevalence. Can J Infect Dis 1994;5 (Suppl D):43D (Abst 76)

8. Centers for Disease Control and Prevention. Birth outcomes following zidovudine therapy in pregnant women. MMWR 1994;43:40,415-6.

Canadian Paediatric Society Infectious Diseases and Immunization Committee

Members: Michael Hall (director responsible), St John's, Newfoundland; Noni E MacDonald (chair), Department of Pediatrics, Children's Hospital of Eastern Ontario, Ottawa. Ontario; William Albritton, Provincial Laboratory of Public Health, Edmonton, Alberta; François Boucher, Département de pédiatrie, Centre hospitalier de I'Université Laval, Ste-Foy, Québec; Gilles Delage, Adjoint médical, Service de transfusion de sang de la Croix-Rouge canadienne, Centre de Montréal, Montréal, Québec; Elizabeth Ford-Jones,

Division of Infectious Disease, The Hospital for Sick Children, Toronto, Ontario: Susan King (principal author), Division of Infectious Disease, The Hospital for Sick Children, Toronto, Ontario: David P Speert, Research Centre, Vancouver, British

Columbia. Ex-Officio Members: Frank R Friesen (Chair, Committee on Committees), Manitoba Clinic, Winnipeg,

Manitoba. Consultants: Ronald Gold, Division of Infectious

Disease, The Hospital for Sick Children, Toronto, Ontario;

Victor Marchessault, Department of Pediatrics, Children's Hospital of Eastern Ontario, Ottawa, Ontario. Liaisons: Public Health, Dr Jacqueline Carlson. Disease Control and Epidemiology, Public Health Branch, Toronto, Ontario; American Academy of Pediatrics, Larry Pickering, Eastern

Virginia Medical School, Children's Hospital of the King's Daughters, Norfolk, Virginia; Centre for Vaccine Evaluation. Dr David Scheifele, Division of Infectious Diseases, Research Centre, BC's Children's Hospital, Vancouver, British Columbia; Epidemiology, Dr John Waters, Alberta Health, Communicable Disease Control, Edmonton, Alberta 


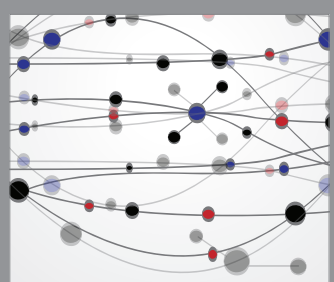

The Scientific World Journal
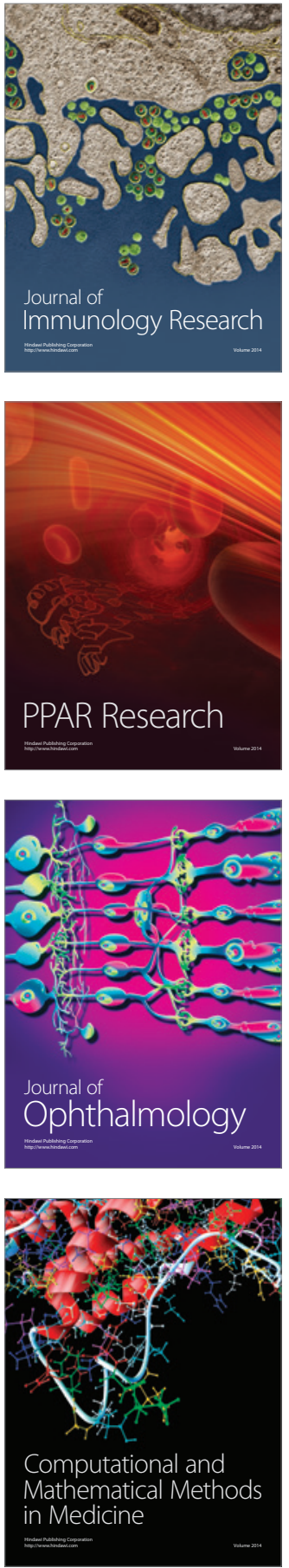

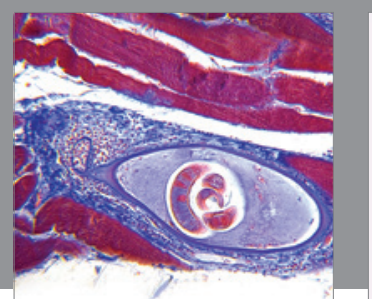

Gastroenterology Research and Practice

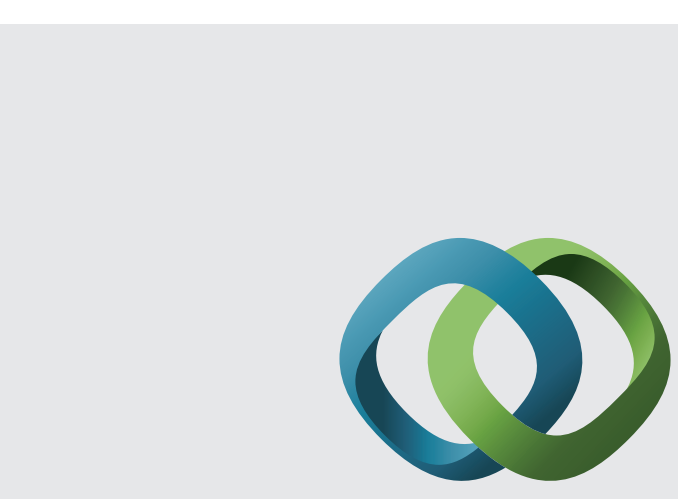

\section{Hindawi}

Submit your manuscripts at

http://www.hindawi.com
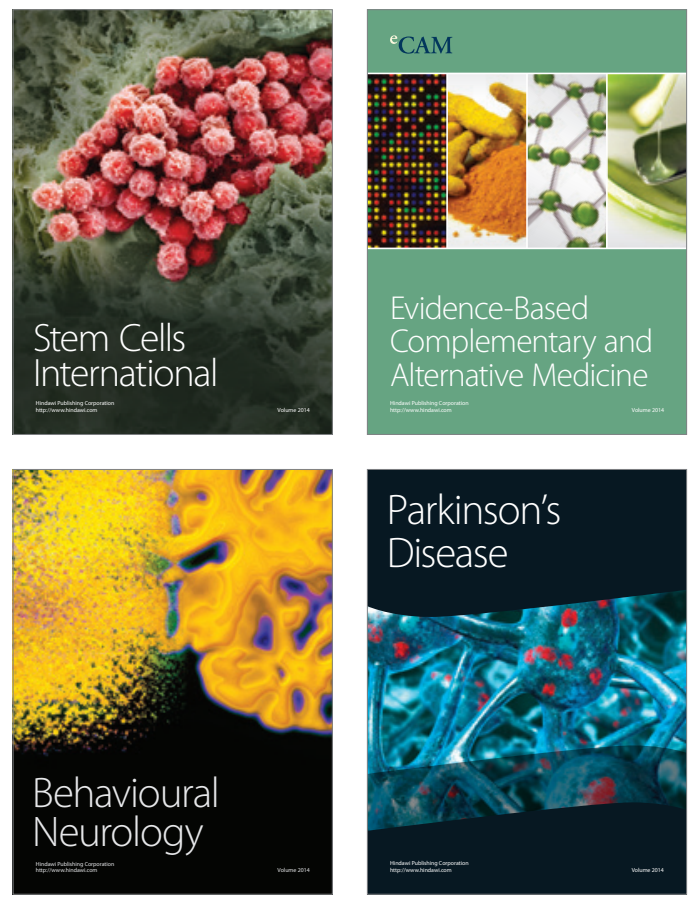
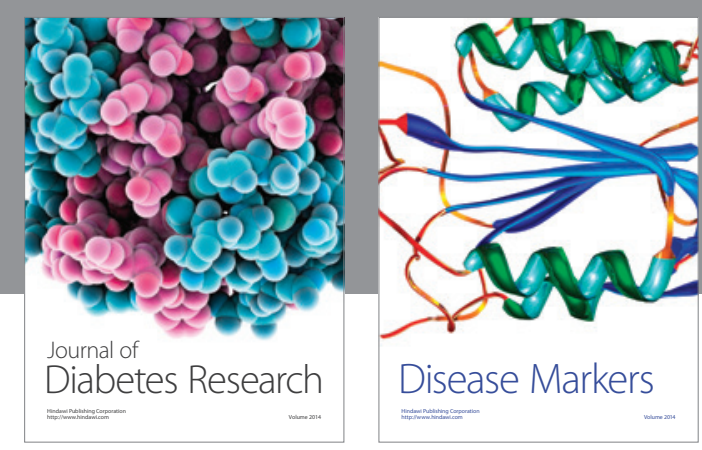

Disease Markers
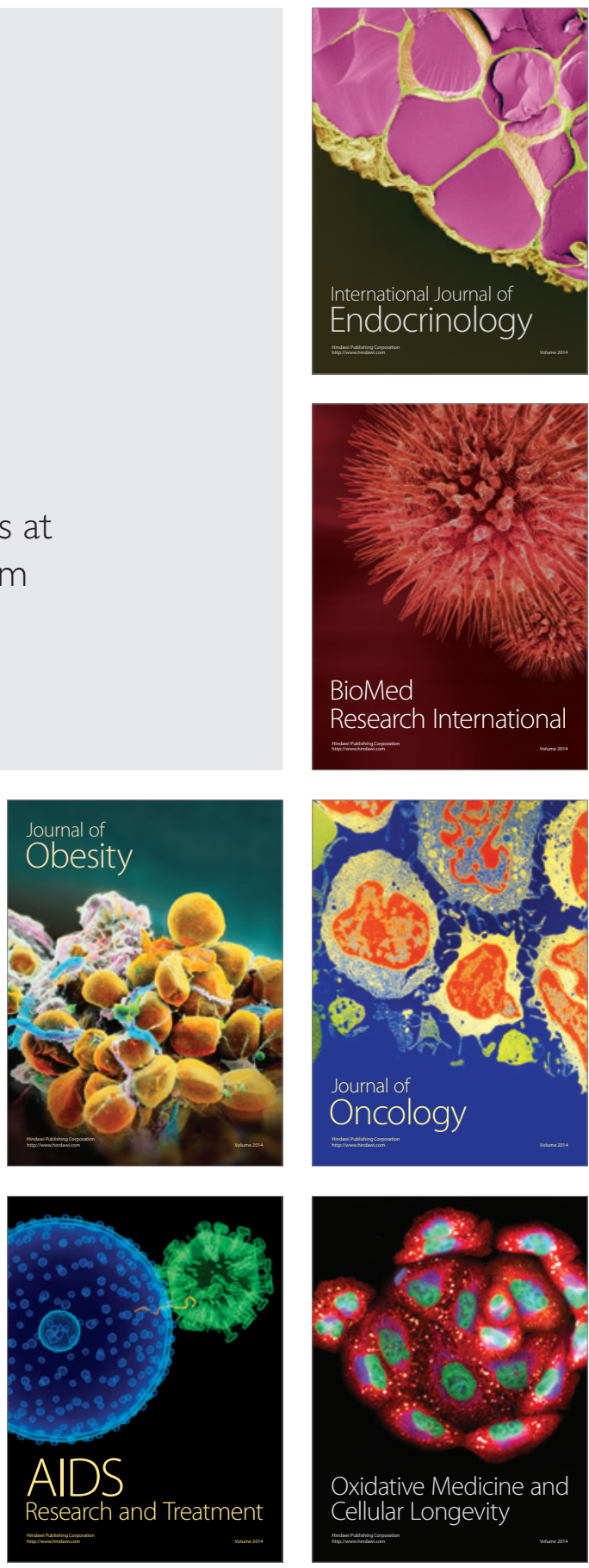